\title{
OBSERVATIONS ON SODIUM CHLORIDE RESTRICTION AND UREA CLEARANCE IN RENAL INSUFFICIENCY ${ }^{2}$
}

\author{
By EUGENE M. LANDIS, K. A. ELSOM, P. A. BOTT and E. SHIELS \\ (From the Department of Medicine and the Department of Pharmacology, \\ University of Pennsylvania, Philadelphia)
}

(Received for publication April 16, 1935)

The azotemia which accompanies hypochloremia has been ascribed by some to transient renal insufficiency of a purely functional type (Haden and Guffey (1924), Mellinghoff (1934)) and in severe cases to grave anatomical changes in the kidney (Brown et al. (1923)). Others believe that renal function per se is essentially unaffected by hypochloremia (Blum, Grabar and Van Caulaert $(1929 a, b))$ and that urea is retained by the body in order that the osmotic pressure of the body fluids may remain unchanged despite chloride loss. Diminished urinary excretion of nitrogen and the resulting azotemia are ordinarily used to measure renal insufficiency with the inherent assumption that renal insufficiency produces nitrogen retention primarily. Hartmann and Darrow (1928) suggest, however, that even in nephritis urea may be retained, not primarily because of reduction in the power of the kidneys to excrete urea but secondarily to compensate for the low osmotic pressure of the body fluids resulting from loss of electrolytes.

Most patients in whom significant hypochloremia is discovered are suffering also from the other effects of vomiting - dehydration, diminished food intake and oliguria. Nitrogen might therefore accumulate in the blood simply because of oliguria (Peters (1932), Kerpel-Fronius and Butler (1935)) and the increased protein destruction of starvation and dehydration (Peters (1932), Meyer (1932), Morawitz and Schloss (1932)). The diminished excretion of phenolsulphonphthalein (Brown et al. (1923)) and of ferments (Mellinghoff (1934)) might also, according to this view, be produced by marked oliguria without primary change in the functioning power of the kidney per se.

Conventional urea clearances with brief periods of urine collection have not revealed any change

1 The cost of this investigation was in large part defrayed by the Commonwealth Fund. in renal function during chloride administration or deprivation. Leiter (1926) varied salt intake and concluded, from functional studies involving 1-hour urine collections, that salt intake had no effect on the excretion of urea or phenolsulphonphthalein. Cope (1933) observed in unselected cases of renal disease that neither the rapid ingestion of 65 grams of sodium chloride nor restriction to 1 gram per day influenced urea clearance when determined over the usual two successive one-hour periods recommended by Möller, McIntosh and Van Slyke (1928).

On the other hand, a prolonged salt-poor diet diminishes the urinary excretion of nonprotein nitrogen (Hatcher and Sollmann (1903), Schoenthal (1929)) and is associated with a slow rise of blood urea nitrogen too frequently to be explained as a coincidence. Rigorous salt restriction and slight or moderate fluid restriction elevated the blood urea nitrogen in 44 of 104 hypertensive cases having no previous clinical evidence of renal insufficiency (Allen and Sherrill (1922)). Under a similar regime 15 of 33 nephritics and 14 of 33 diabetics showed a rising blood urea nitrogen. Allen and Sherrill state that occasionally salt restriction must be made less rigid when blood urea nitrogen rises too rapidly, or too much. McLester (1922) in repeating the observations of Allen and Sherrill found, in 7 of 10 hypertensive patients, that blood urea nitrogen and creatinine rose during salt restriction.

The relation between sodium chloride restriction and kidney function is admittedly an extremely difficult problem owing to the many factors involved. While variations in sodium chloride intake have often seemed to affect the renal elimination of nitrogen there is considerable conflict in both data and interpretation. It appeared that studies carried out by a slightly different approach might yield additional information concerning possible changes in renal function during 
the administration and restriction of sodium chloride.

The figures of McLester (1922) indicate that blood urea nitrogen may rise at the rate of $1 \mathrm{mgm}$. per 100 cc. per day when salt is restricted. Calculation shows that, if urea be distributed through 70 per cent of body weight, to increase the concentration of urea nitrogen by $1 \mathrm{mgm}$. per 100 cc. per day in a 70 kilo man would require the retention of $500 \mathrm{mgm}$. of urea nitrogen and a decrease of 24-hour excretion from a normal of 10 grams to 9.5 grams per day. If protein intake and metabolism remain constant, retention of urea nitrogen at this rate would indicate that urea clearance had been diminished by 5 per cent, e.g. from 100 to 95 per cent of normal. Urea nitrogen would be eliminated once more at the rate of 10 grams per day when the blood urea nitrogen became high enough to compensate for the reduced clearance. Such small changes in renal function will be difficult to detect by direct studies of urea clearance, though the cumulative effect of slightly decreased urea clearance might well produce in the course of days a significant rise in the concentration of blood urea nitrogen.

It is doubtful whether any practicable number of 2-hour urea clearances would reveal changes in renal function amounting even to 10 or 15 per cent because, as usually determined, urea clearance varies widely in the same individual. Bruger and Mosenthal (1932) state that urea clearance may vary as much as 100 per cent from hour to hour or from day to day in the same individual. This variability lessens as renal function diminishes in the course of disease, but successive determinations still show but little constancy. Thus Page (1934) records for single patients urea clearances which vary as much as 50 per cent even when two 1-hour clearances are averaged. When the clearances during single 1-hour periods are compared the variation is greater. Van Slyke, Alving and Rose (1932) report urea clearances ranging on the same day from 3.4 to 12.2 per cent af normal in a patient with terminal hemorrhagic nephritis.

It seemed possible that routine urea clearance determinations (Cope) and "urea concentration indices" (McLean) failed to reveal changes in renal function during salt deprivation because spontaneous variations in renal function over brief periods were far greater than the relatively small changes that were to be measured. Therefore, in the studies described in this paper urea clearances were determined in 2 normal subjects during short (1-hour) and long (24-hour) periods of urine collection. Having found that prolonging the period of urine collection diminished to a certain extent the variability of the urea clearance figures, the method was applied to the study of changes in renal function during salt deprivation in three cases of renal insufficiency, one with hypochloremia and marked azotemia, two with normal plasma chlorides and trifling elevations of blood urea nitrogen.

While the observed changes in 24-hour urea clearance were small, the direction of change was similar in all 3 patients, the blood urea nitrogen tending to rise, the urea clearance tending to fall when the intake of sodium chloride was diminished. The observations are described not as conclusive evidence but as findings which suggest that this method of study applied to other cases with conspicuous hypochloremia may aid in reconciling certain divergent views now expressed in the literature.

\section{METHODS}

The patients were placed under special and continuous nursing care with rigid supervision of food and fluid intake. Each article of diet was weighed accurately and the amount returned was recorded, so that the dietary figures represent the amount actually eaten. Sodium chloride, when administered, was dissolved in the drinking water. Urine was collected with scrupulous care over periods of 12 or 24 hours from 8:00 to 8:00, any deviation being recorded to the nearest minute. If a urine specimen was contaminated by feces the whole 12- or 24-hour collection was discarded. Blood samples were taken before breakfast to obtain fasting concentrations. The urea nitrogen in blood plasma was determined by the method of Van Slyke and Cullen (1914). Urinary urea nitrogen was determined by the same method after ammonia had been removed with permutit. Eisenman's (1929) modification of the Van Slyke and Sendroy method was used for the estimation of chloride in plasma and urine. On determining plasma chlorides a mixture of 95 per cent oxygen 
and 5 per cent carbon dioxide was passed through whole blood slowly under oil for about $20 \mathrm{~min}$ utes before the plasma was separated. Creatinine in plasma and urine was determined by the method of Folin as used by Holten and Rehberg (1931). In order to keep the concentration of creatinine sufficiently high for color comparison it was occasionally necessary to dilute the plasma only five times instead of the usual ten.

The specific gravity of urine was determined by means of a pyknometer containing 25 cc. The total protein of urine was estimated by the gravimetric method of Folin and Denis (1914). The precipitated urinary proteins were dried overnight in an oven at $105^{\circ} \mathrm{C}$. before weighing.

The range of variations in 1-hour and 24-hour urea clearances in two normal subjects

It was the purpose of these preliminary observations to determine whether urea clearances determined over periods of 24 hours were significantly more constant than urea clearances determined over the conventional 1-hour periods.

The urine of 2 normal subjects was collected in 24-hour periods extending approximately from 8 a.m. of one day to 8 a.m. of the day following. The exact duration of each period was recorded to the nearest minute. No attempt was made to modify or control diet, fluid intake, environmental temperature or activity. Each completed specimen of urine was well mixed and its volume and urea nitrogen content were recorded. Venous blood samples for determining plasma urea nitrogen were collected twice daily, before breakfast and after the evening meal.

The results of these observations are shown in Table I. The urea clearances for the 24-hour periods were calculated as per cent of normal according to the equations of Möller, McIntosh and Van Slyke (1928). In these studies on normal subjects the average rate of urine formation was always below $2.0 \mathrm{cc}$. per minute so that the calculated 24-hour urea clearances were all "standard clearances."

The calculation of such 24-hour urea clearances introduces no objections which cannot be raised against 2-hour clearances; the difference being one of degree alone. The Van Slyke corrections for "maximal" and "standard" clearances were used since the effect of diuresis per se on the efficiency of urea excretion was thus eliminated as far as possible. It may be mentioned that neglecting this correction and calculating urea clearances simply in terms of "cc. per minute" (i.e.

TABLE I

Urea clearances over 24-hour periods

\begin{tabular}{c|c|c|c|c|c|c|c}
\hline \hline \multirow{2}{*}{$\begin{array}{c}\text { 24-hour } \\
\text { periods }\end{array}$} & \multicolumn{2}{|c|}{ Plasma urea nitrogen } & \multicolumn{2}{|c|}{ Urine } & 24-hour urea clearance \\
\cline { 2 - 5 } & Fasting & $\begin{array}{c}\text { After } \\
\text { evening meal }\end{array}$ & $\begin{array}{c}\text { Urea } \\
\text { Rate of } \\
\text { formation }\end{array}$ & $\begin{array}{c}\text { Urea } \\
\text { nitrogen }\end{array}$ & elimination & $\begin{array}{c}\text { Using average } \\
\text { plasma urea } \\
\text { nitrogen }\end{array}$ & $\begin{array}{c}\text { Using fasting } \\
\text { plasma urea } \\
\text { nitrogen only }\end{array}$ \\
\hline & mgm. per cent & mgm. per cent & cc. per minute & mgm. per cent & grams per 24 hours & per cent normal & per cent normal \\
\hline
\end{tabular}

A. Subject K. E., 7 days.

\begin{tabular}{r|r|r|r|r|r|r|r}
\hline 1 & 12.0 & 14.4 & .99 & 704 & 10.0 & 98 & 108 \\
2 & 12.7 & 14.2 & .72 & 902 & 9.4 & 112 & 91 \\
3 & 13.2 & 14.4 & .79 & 761 & 8.7 & 95 \\
4 & 12.0 & 14.6 & .69 & 887 & 8.8 & 103 & 90 \\
5 & 11.4 & 10.0 & 1.20 & 476 & 8.2 & 14 \\
6 & 10.0 & 11.5 & .83 & 762 & 9.1 & 119 & 128 \\
7 & 10.0 & 15.0 & .75 & 792 & 8.6 & 102 & 127 \\
\hline
\end{tabular}

B. Subject E. M. L., 5 days.

\begin{tabular}{l|l|l|l|r|r|r|r}
\hline 1 & 10.4 & 12.2 & .63 & 867 & 7.9 & 112 & 122 \\
2 & 10.3 & 13.5 & .85 & 846 & 10.4 & 121 & 140 \\
3 & 11.8 & 14.8 & .78 & 1174 & 13.2 & 144 & 163 \\
4 & 12.0 & 17.1 & 1.02 & 893 & 13.1 & 14 & 139 \\
5 & 15.0 & 15.0 & 1.03 & 887 & 13.2 & 111 \\
\hline
\end{tabular}


analogous to maximal clearance) led to the same conclusion as the calculations of "standard" clearance. It is recognized also that if absolute urea clearances were to be determined many blood samples should be taken during each 24-hour period. For comparative studies in individual patients it seemed advisable to take fewer blood samples and to multiply the number of periods, since it is manifestly impossible to perform venipunctures at intervals of 1 or 2 hours day after day.

No correction was made for surface area since variations in given subjects were being studied, when determined over 1-hour periods in the same subject. The latter figures were obtained in the course of studies on the effect of environmental temperature on urea clearance but are quite comparable to the 24-hour clearances in which environmental temperature also varied considerably. The conventional technique was followed; urine was collected over two successive 1-hour periods with a blood sample at the end of the first hour. In addition breakfast was omitted. In half the determinations the subject was semirecumbent, in the other half he was walking about the room.

The average values recorded in the first column

TABLE II

Comparison of variation of 24-hour and 1-hour urea clearances

\begin{tabular}{|c|c|c|c|c|}
\hline & Average & Highest & Lowest & $\begin{array}{l}\text { Maximum variation } \\
\text { from average }\end{array}$ \\
\hline & per cent normal & per cent normal & per cent normal & per cent \\
\hline
\end{tabular}

A. Subject K. E.

\begin{tabular}{|c|c|c|c|c|}
\hline $\begin{array}{l}\text { Calculations based on } 7 \text { 24-hour periods } \\
\text { (a) from average plasma urea nitrogen } \ldots \ldots \ldots \ldots \\
\text { (b) from fasting plasma urea nitrogen } \ldots \ldots \ldots \ldots\end{array}$ & $\begin{array}{l}101 \\
110\end{array}$ & $\begin{array}{l}119 \\
128\end{array}$ & $\begin{array}{l}90 \\
85\end{array}$ & $\begin{array}{l}+18,-11(29) \\
+16,-23(39)\end{array}$ \\
\hline Calculations based on 81 -hour periods. . . . . . . . & 87 & 106 & 63 & $+22,-28(50)$ \\
\hline
\end{tabular}

B. Subject E. M. L.

\begin{tabular}{|c|c|c|c|c|}
\hline $\begin{array}{l}\text { Calculations based on } 5 \text { 24-hour periods } \\
\text { (a) from average plasma urea nitrogen } \ldots \ldots \ldots \ldots \\
\text { (b) from fasting plasma urea nitrogen } \ldots \ldots \ldots \ldots\end{array}$ & $\begin{array}{l}120 \\
135\end{array}$ & $\begin{array}{l}144 \\
163\end{array}$ & $\begin{array}{l}111 \\
111\end{array}$ & $\begin{array}{l}+20,-8(28) \\
+21,-18(39)\end{array}$ \\
\hline Calculations based on 12 1-hour periods. . . . . . . . & 110 & 178 & 80 & $+62,-27(89)$ \\
\hline
\end{tabular}

absolute values being of secondary interest. The clearances were, however, calculated in two ways -(a) using the average of night and morning plasma urea nitrogen and (b) using fasting plasma urea nitrogen only. Except for one day in each subject the plasma urea nitrogen was higher in the evening than in the morning. Therefore the absolute figures for 24-hour urea clearances were lower when calculations were based on both morning and evening plasma urea nitrogen than when calculations were based on fasting plasma urea nitrogen alone. On successive days there was no consistent relation between changes in 24-hour urea clearance and total urea nitrogen output.

Table II compares the variation in urea clearance when determined over 24-hour periods and of Table II all fell within the limits of normal. For each subject the average 24-hour clearance was higher than the average 1-hour clearance; this difference is, however, of little significance since the two series were not carried out simultaneously. Attention is called particularly to the lessened variability of urea clearance figures when urine is collected over longer periods. Twentyfour hour urine collections with a single (fasting) blood urea nitrogen yielded urea clearances whose total variation was rather less (39 per cent compared to 50 and 89 per cent) than that of the conventional urea clearance.

To detect possible small changes in urea clearance it seemed advisable therefore to use 12- or 24-hour urine specimens (a) because normal varia- 
tion is slightly less and (b) because the continuous collection of urine gives a more complete average picture of urea elimination than would isolated samples of urine collected over briefer periods. The absolute urea clearance figures obtained by these longer periods of urine collection cannot at present be compared directly with the average normal established by Möller, McIntosh and Van Slyke (1928) who used shorter periods of collection. This limitation, however, does not invalidate the use of this method for detecting changes in urea excretion by a given individual under different regimes.

\section{Sodium chloride administration and 24-hour urea clearance in patients with renal insufficiency}

Case 1, A. P., female aged 43 , married, was admitted to the hospital first on May 23, 1934, primarily for arthritic symptoms. In the course of study hypertension (180 systolic, 100 diastolic) and retinal sclerosis were discovered. The blood urea nitrogen was $108 \mathrm{mgm}$. per $100 \mathrm{cc}$. and routine urine examinations showed abundant albumin, low specific gravity, few or no casts and many red cells. A concentration test and cast count performed when the blood urea nitrogen was lower yielded the following results :

Restriction of fluid for 24 hours (Addis) elevated the specific gravity of the urine to only 1.010 . The 12-hour volume was $450 \mathrm{cc}$, the reaction acid. Cast excretion totalled 24,000 per 12 hours with 30 per cent each of hyaline, granular and epithelial casts and 10 per cent of failure casts. Erythrocyte excretion was 15.0 million per 12 hours, leukocyte and epithelial cell excretion 1.0 million per 12 hours. The plasma protein percentage was normal and proteinuria amounted to 0.56 gram per 12 hours. Phenolsulphonphthalein elimination was 7 per cent in the first hour and less than 5 per cent in the second hour. Several 2-hour urea clearances indicated from 3 to 12 per cent of normal function. Chloride elimination (reported in terms of $\mathrm{NaCl}$ ) was 2.38 grams per day; the plasma contained 102 milliequivalents of chloride per liter.

Under a regime of moderately increased fluid intake and low protein diet with salt ad lib., the plasma urea nitrogen fell to $50.9 \mathrm{mgm}$. per $100 \mathrm{cc}$. and remained almost stationary. From June 4 to 10 (Table III) sodium chloride was administered in dosage of 10 grams per day while creatinine and urea clearances were followed in a preliminary way. The rate of urine formation varied between 1.01 and $1.77 \mathrm{cc}$. per minute; blood urea nitrogen fell from 50.9 to $34.6 \mathrm{mgm}$. per $100 \mathrm{cc}$., the $24-$ hour urea clearance changing simultaneously from 4.7 to 8.3 per cent of normal. Chloride excretion was conspicuously below chloride intake during the first few days but rose finally to 15.8 grams on the seventh day of salt administration. The plasma chloride level was not appreciably altered.

During the next 6 days no sodium chloride was given except that contained in the diet. Chloride elimination, plasma chloride concentration and the 24-hour urea clearance diminished. Urea clearance fell from over 7.0 to 3.0 per cent of normal while plasma urea nitrogen simultaneously rose from 34.6 to $40.1 \mathrm{mgm}$. per $100 \mathrm{cc}$. The concentration of creatinine in plasma was high enough $(6.95 \mathrm{mgm}$. per $100 \mathrm{cc}$.) to allow determining reasonably accurate creatinine clearances. The average creatinine clearance during sodium chloride administration was 10.1 cc. per minute. When salt was not added to the diet the creatinine clearance averaged $7.3 \mathrm{cc}$. per minute. Plasma creatinine fell from 6.95 to $6.1 \mathrm{mgm}$. per $100 \mathrm{cc}$. during sodium chloride administration, rising to $7.3 \mathrm{mgm}$. per $100 \mathrm{cc}$. when dietary salt alone was given. The patient was discharged with a blood urea nitrogen of 38 mgm. per $100 \mathrm{cc}$. and was advised to follow a regime of

TABLE III

Case 1. Effect of sodium chloride administration on urea and creatinine clearances with only partially controlled diet and moderate fluid intake

\begin{tabular}{|c|c|c|c|c|c|c|c|c|}
\hline Date & $\begin{array}{l}\mathrm{NaCl} \\
\text { added } \\
\text { to diet }\end{array}$ & $\begin{array}{l}\text { Chloride } \\
\text { excretion } \\
\text { (as NaCl) }\end{array}$ & $\begin{array}{l}\text { Plasma } \\
\text { chloride }\end{array}$ & 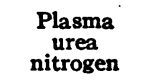 & $\begin{array}{c}\text { Plasma } \\
\text { creatinine }\end{array}$ & $\begin{array}{c}\text { Urine } \\
\text { formation }\end{array}$ & $\begin{array}{l}\text { 24-hour } \\
\text { urea } \\
\text { clearance }\end{array}$ & $\begin{array}{l}\text { 24-hour } \\
\text { creatinine } \\
\text { clearance }\end{array}$ \\
\hline $\begin{array}{r}\text { June } 4 \ldots \\
5 \ldots \\
6 \ldots \\
7 \ldots \\
8 \ldots \\
9 \ldots \\
10 \ldots \\
11 \ldots \\
12 \ldots \\
13 \ldots \\
14 \ldots \\
15 \ldots \\
16 \ldots \\
16 \\
\end{array}$ & $\begin{array}{c}\text { grams per } \\
\text { \&4 hours } \\
10 \\
10 \\
10 \\
10 \\
10 \\
10 \\
10 \\
0 \\
0 \\
0 \\
0 \\
0 \\
0\end{array}$ & $\begin{array}{c}\text { grams per } \\
84 \text { hours } \\
\\
7.9 \\
8.3 \\
10.0 \\
11.5 \\
12.5 \\
15.8 \\
11.7 \\
9.0 \\
7.0 \\
5.6 \\
7.9\end{array}$ & $\begin{array}{c}\text { m.eq. per liter } \\
106.1 \\
106.1 \\
106.6 \\
107.1 \\
101.8\end{array}$ & $\begin{array}{c}\text { mgm. per cent } \\
50.9 \\
42.4 \\
38.0 \\
34.6 \\
36.8\end{array}$ & $\begin{array}{c}\text { mgm per cent } \\
6.95 \\
6.3 \\
6.1 \\
6.1 \\
6.6\end{array}$ & $\begin{array}{c}c c . \text { per minute } \\
\\
1.16 \\
1.18 \\
1.30 \\
1.39 \\
1.48 \\
1.77 \\
1.42 \\
1.22 \\
1.08 \\
1.01 \\
1.53\end{array}$ & $\begin{array}{l}4.7 \\
5.6 \\
7.2 \\
7.8 \\
6.7 \\
8.3 \\
7.7 \\
5.4 \\
5.7 \\
5.7 \\
3.0\end{array}$ & $\begin{array}{r}10.4 \\
11.1 \\
10.7 \\
6.4 \\
11.9 \\
7.3 \\
8.5 \\
5.0 \\
8.3 \\
7.5\end{array}$ \\
\hline
\end{tabular}


low protein diet and high fluid intake, adding salt freely to food during and after preparation.

Five months later the patient was again-referred to the hospital on account of anorexia, nausea and slight weakness; she had not vomited and was ambulatory. On admission to the Renal Ward, plasma urea nitrogen was $161 \mathrm{mgm}$. per 100 cc., plasma chloride 94 m.eq. per liter, plasma creatinine $7.2 \mathrm{mgm}$. per $100 \mathrm{cc}$. and serum phosphates $7.3 \mathrm{mgm}$. per $100 \mathrm{cc}$. The results of clinical tests of renal function were essentially similar to those obtained during the previous admission. The patient was then submitted to rigidly controlled study as described under "Methods." The diet provided 2100 calories per day with 0.5 gram of protein per kilo. Fluid intake was kept rigidly at $4500 \mathrm{cc}$. per day, of which $3090 \mathrm{cc}$. consisted of $0.45 \mathrm{NaCl}$ solution, so that 13.9 grams of salt were added daily to a diet which was of itself salt-poor, offering less than 1.0 gram of $\mathrm{NaCl}$ per day.
Figure 1 shows the plasma urea nitrogen (circles), plasma chlorides (crosses) and 24-hour urea clearances (dots) over a period of 53 days during which fluid intake was kept constant while dietary protein and salt were varied independently. To detect possible diurnal variations the urea clearances were computed for two 12-hour periods daily by means of the usual equations for " standard" and " maximal" clearances. Each dot represents, therefore, the average of one day and one night urea clearance. In the lower part of Figure 1, to make comparison easier, the rates of urine formation and urea clearances are shown also by shaded areas which represent average values over periods of 3 to 6 days. The urea clear-

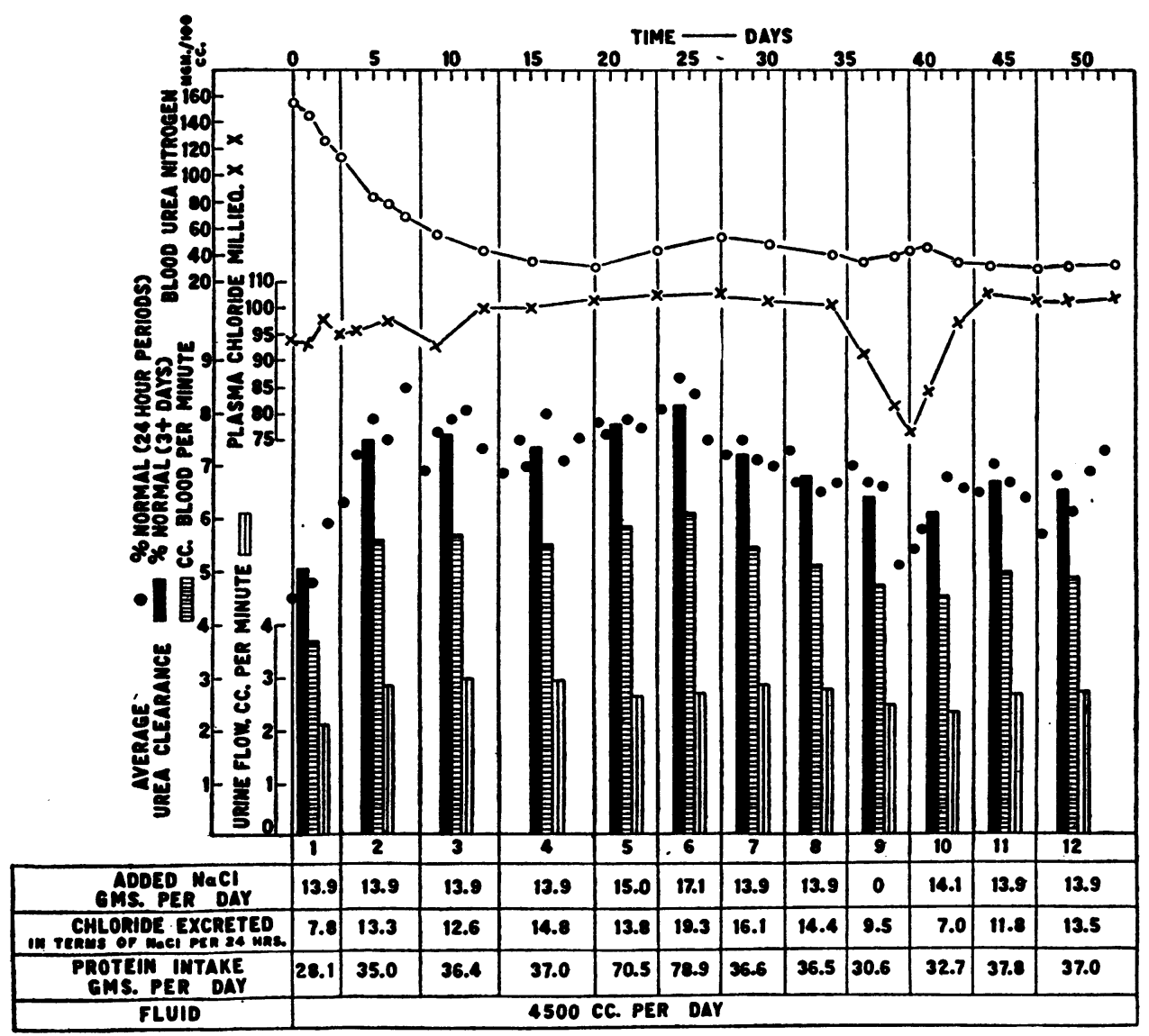

Fig. 1. Case 1. Showing Effects of Administering and Restricting Sodium Chloride in a Patient with Advanced Renal Insufficiency.

a. Periods 1 to 4 -low protein, high salt intake.

b. Periods 5 and 6 -increased protein, high salt intake.

c. Periods 7 and 8 - similar to a.

d. Period 9-low protein intake with salt restriction.

e. Periods 10 to 12 -similar to a and c. 
ances are expressed (a) in terms of cc. of blood cleared per minute (horizontal shading) and (b) in terms of per cent of normal (solid) using the Van Slyke equations.

The clinical course of this patient can be described best according to regime:

\section{(a) Low protein, high salt intake (Periods 1 to 4, duration 19 days)}

Although 37 grams of protein were offered in the daily diet, anorexia restricted the amount taken during the first 2 days so that in Period 1 the protein intake was only 28.1 grams per day. Thereafter the diet was taken almost completely as offered. Fluid intake was $4500 \mathrm{cc}$. per day from the start, but the urinary output during Period 1 (3 days) was only slightly above $2.0 \mathrm{cc}$. per minute. During this interval weight increased from 163 to 166 pounds and considerable chloride was retained as shown by the difference between the intake and excretion of chloride. After chloride balance was attained the rate of urine formation exceeded $2.5 \mathrm{cc}$. per minute and weight increased more slowly, reaching 167 pounds by the thirteenth day.

The plasma chlorides rose from 94 to 100 m.eq. per liter, plasma urea nitrogen fell from 154 to $32.8 \mathrm{mgm}$. per $100 \mathrm{cc}$., plasma creatinine from 7.2 to $5.0 \mathrm{mgm}$. per $100 \mathrm{cc}$., and serum phosphates from 7.3 to $4.9 \mathrm{mgm}$. per $100 \mathrm{cc}$. The 24-hour urea clearance rose abruptly during the first 5 days from 4.5 to 7 per cent of normal, averaging for the next 14 days 7.3 per cent of normal.

\section{(b) Increased protein, high salt intake (Periods 5 and 6, duration 8 days)}

The protein intake was increased from 0.5 to 1.0 gram per kilo and the salt intake was slightly increased while all other things were kept constant. The blood urea nitrogen, previously falling slowly but consistently, rose from 32.8 to 54.5 mgm. per 100 cc., plasma creatinine from 5.0 to $5.5 \mathrm{mgm}$. per $100 \mathrm{cc}$., and plasma phosphate from 5.0 to $6.9 \mathrm{mgm}$. per $100 \mathrm{cc}$. The urea clearances for these two 4-day periods (Numbers 5 and 6) were the highest observed in this patient.

Protein intake was thus increased in order to be certain (1) that the blood urea nitrogen was not falling merely because of high fluid intake and (2) that the patient's inability to excrete nitrogen was demonstrable not only by a low urea clearance but also by a rising blood urea nitrogen on a liberal intake of salt with a diet which normally produces no azotemia.

\section{(c) Repetition of low protein, high salt intake (Periods 7 and 8, duration 8 days)}

Having ascertained that the patient could not excrete all the nitrogen arising from a protein intake of 1 gram per kilo daily, the dietary protein was reduced to the initial value of $0.5 \mathrm{gram}$ per kilo, with 13.9 grams of salt per day.

The plasma urea nitrogen fell from 54.5 to $38.3 \mathrm{mgm}$. per $100 \mathrm{cc}$, and the 24-hour urea clearances again varied between 6 and 7 per cent of average normal.

\section{(d) Low protein, low salt intake (Period 9, dura- tion 4 days)}

In this period no additional sodium chloride was administered. Activity, salt-poor diet and fluid intake were not changed. The plasma chlorides fell rapidly from 100 to 76 m.eq. per liter. Abundant chloride excretion continued, however, and weight decreased by 4 pounds in 3 days. The plasma urea nitrogen, which had previously been falling consistently, rose from 38.3 to $41.5 \mathrm{mgm}$. per $100 \mathrm{cc}$. Weakness, dizziness, anorexia and muscular stiffness developed on the third day. This was followed by nocturnal cramps in the calf muscles, generalized muscular stiffness on waking the next day, nausea, vomiting (only once) and some reluctance to take fluids and food. The anorexia is reflected in the lower protein intake during period 9.

On the last day of this period the total intake of fluid was $2500 \mathrm{cc}$. - the only instance in which fluid intake varied from $4500 \mathrm{cc}$. per 24 hours. Any changes in renal function cannot therefore be ascribed to dehydration in the ordinary sense of the word, nor to oliguria since the urinary output averaged more than 3000 cc. per 24 hours. Urea clearance, which had previously been dropping very slowly from the level attained during the period of increased protein intake, changed very little until the latter part of the period of restricted salt intake when the clearance dropped to a minimum figure of 4.3 per cent (see Table 
TABLE IV

Case 1. Effect of sodium chloride restriction on urea and creatinine clearances with controlled salt-poor diet and high fluid intake

\begin{tabular}{|c|c|c|c|c|c|c|c|c|}
\hline Date & $\begin{array}{c}\mathrm{NaCl} \\
\text { added to } \\
\text { diet }\end{array}$ & $\begin{array}{l}\text { Chloride } \\
\text { excretion } \\
\text { (as NaCl) }\end{array}$ & $\begin{array}{l}\text { Plasma } \\
\text { chloride }\end{array}$ & $\begin{array}{c}\text { Plasma } \\
\text { urea } \\
\text { nitrogen }\end{array}$ & $\underset{\text { creatinine }}{\text { Plasma }}$ & $\begin{array}{c}\begin{array}{c}\text { Rate of } \\
\text { urine } \\
\text { formation }\end{array}\end{array}$ & $\begin{array}{c}\text { 12-hour } \\
\text { urea } \\
\text { clearance }\end{array}$ & $\begin{array}{l}\text { 12-hour } \\
\text { creatinine } \\
\text { clearance }\end{array}$ \\
\hline December 4 & $\begin{array}{c}\text { grams per } \\
24 \text { hours } \\
13.9\end{array}$ & $\begin{array}{c}\text { grams per } \\
24 \text { hours } \\
14.0\end{array}$ & $\begin{array}{c}\text { m.eq. per liter } \\
101\end{array}$ & $\begin{array}{c}\text { msm. per cent } \\
40.0\end{array}$ & $\begin{array}{c}\text { mgm. per cent } \\
5.5\end{array}$ & $\begin{array}{c}\text { cc. per minute } \\
2.38 \\
3.04^{*}\end{array}$ & $\begin{array}{c}\text { per cent normal } \\
6.3 \\
7.1^{*}\end{array}$ & $\begin{array}{c}\text { cc. per minule } \\
10.4\end{array}$ \\
\hline 5 & 0 & 12.1 & & & & $\begin{array}{l}2.74 \\
2.63\end{array}$ & $\begin{array}{l}7.3 \\
6.7\end{array}$ & $\begin{array}{l}10.6 \\
7.8^{*}\end{array}$ \\
\hline 6 & 0 & 9.2 & 91 & 38.3 & 5.5 & $\begin{array}{l}2.64 \\
2.58\end{array}$ & $\begin{array}{l}6.8 \\
6.6\end{array}$ & $\begin{array}{l}7.9 \\
7.8\end{array}$ \\
\hline 7 & 0 & 9.1 & & & & $\begin{array}{l}2.63 \\
3.06\end{array}$ & $\begin{array}{l}6.4 \\
7.2\end{array}$ & $\begin{array}{r}8.2 \\
10.6\end{array}$ \\
\hline 8 & 0 & 3.4 & 81 & 39.4 & 5.8 & $\begin{array}{l}1.76 \\
1.83\end{array}$ & $\begin{array}{l}5.9 \\
4.3\end{array}$ & $\begin{array}{l}7.3 \\
6.2\end{array}$ \\
\hline 9 & 14.6 & 3.9 & 76 & 41.2 & 4.4 & $\begin{array}{l}1.62 \\
2.30\end{array}$ & $\begin{array}{l}4.9 \\
5.9\end{array}$ & $\begin{array}{r}8.4 \\
10.5\end{array}$ \\
\hline 10 & 13.9 & 5.7 & 84 & 41.5 & 4.3 & $\begin{array}{l}1.83 \\
2.60\end{array}$ & $\begin{array}{l}5.1 \\
6.5\end{array}$ & $\begin{array}{r}9.6 \\
12.0\end{array}$ \\
\hline 11 & 13.9 & 8.5 & & & & $\begin{array}{l}2.20 \\
2.88\end{array}$ & $\begin{array}{l}6.2 \\
7.4\end{array}$ & $\begin{array}{l}10.5 \\
11.7\end{array}$ \\
\hline 12 & 13.9 & 9.8 & 96 & 37.6 & 4.5 & $\begin{array}{l}2.80 \\
2.44\end{array}$ & $\begin{array}{l}6.7 \\
6.4\end{array}$ & $\begin{array}{r}10.9 \\
9.9\end{array}$ \\
\hline 13 & 13.9 & 10.1 & & & & $\begin{array}{l}2.69 \\
2.55\end{array}$ & $\begin{array}{l}6.4 \\
6.6\end{array}$ & $\begin{array}{l}10.9 \\
10.4\end{array}$ \\
\hline 14 & 13.9 & 10.8 & 105 & 33.0 & 4.2 & $\begin{array}{l}2.66 \\
2.44\end{array}$ & $\begin{array}{l}6.8 \\
7.3\end{array}$ & $\begin{array}{l}11.1 \\
10.2\end{array}$ \\
\hline 15 & 13.9 & 12.1 & & & & $\begin{array}{l}2.92 \\
2.54\end{array}$ & $\begin{array}{l}7.1 \\
6.4\end{array}$ & $\begin{array}{r}10.0 \\
9.7\end{array}$ \\
\hline 16 & 13.9 & 14.0 & & & & $\begin{array}{l}3.06 \\
2.81\end{array}$ & $\begin{array}{l}6.6 \\
6.2\end{array}$ & $\begin{array}{r}10.2 \\
9.8\end{array}$ \\
\hline 17 & 13.9 & 11.6 & 101 & 31.8 & 4.5 & $\begin{array}{l}2.64 \\
2.44\end{array}$ & $\begin{array}{l}5.6 \\
5.8\end{array}$ & $\begin{array}{l}9.6 \\
7.9\end{array}$ \\
\hline 18 & 13.9 & 15.3 & & & & $\begin{array}{l}3.15 \\
2.80\end{array}$ & $\begin{array}{l}7.1 \\
6.6\end{array}$ & $\begin{array}{l}9.9 \\
9.1\end{array}$ \\
\hline 19 & 13.9 & 13.0 & 103 & 32.8 & 4.0 & $\begin{array}{l}2.96 \\
2.47\end{array}$ & $\begin{array}{l}6.2 \\
6.1\end{array}$ & $\begin{array}{r}10.1 \\
9.3\end{array}$ \\
\hline
\end{tabular}

* Lower figure of each pair applies to period from 8 p.m. to 8 a.m., upper to period from 8 a.m. to 8 p.m.

IV) for 12 hours, and an average of 5.1 per cent for 24 hours. This figure was lower than any observed during the 30 days immediately preceding Period 9 when sodium chloride was supplied freely.

It may be objected that the change in urea clearance appeared too late to be related to the restriction of sodium chloride. The patient lost 4 pounds of weight during Period 9, chloride excretion remaining above 9 grams per day until the last day when it reached 3.4 grams per day. Contraction of body fluids would free sodium chloride for excretion, the effects of lack of sodium chloride appearing only when this compensation was exhausted. This lag of several days in the excretory manifestations of sodium chloride withdrawal and administration has already been noted (Rowntree and Fitz (1913), Vallery Radot (1918), Leiter (1926)). In Case 1 the urea clearance reached its earlier level of 6 to 7 per cent 
only after $\mathbf{4 0}$ grams of salt had been given, this lag tending to make the average changes in urea clearances over 4 to $\mathbf{5}$ days (shaded areas, Figure 1) considerably less informative than the changes in consecutive 24-hour urea clearances.

\section{(e) Resumed low protein, high salt intake (Pe- riods 10 to 12, duration 13 days)}

Without other change of regime sodium chloride was again administered in the dosage of 13.9 grams per day. The symptoms of hypochloremia disappeared within 3 days. Appetite returned, fluids were taken easily and muscular stiffness disappeared. Chloride was retained and body weight increased from 162 to 166 pounds in 4 days. The plasma chlorides returned to normal, the blood urea nitrogen ceased rising and fell gradually to $32 \mathrm{mgm}$. per $100 \mathrm{cc}$. The urea clearance, both in 24-hour periods and in the averages of 4 days (Period 10), was low while plasma chloride was still below normal. During the last 9 days (Periods 11 and 12) the urea clearance was once more between 6 and 7 per cent.

Chief interest attaches to the changes induced by restricting chloride intake in Period 9. Hypochloremia developed with surprising rapidity, and the symptoms produced were relieved equally rapidly as soon as sodium chloride was again administered. The symptoms resemble those produced by loss of sodium chloride (Moss (1923), Talbott and Michelsen (1933), Derrick (1934)). Blood pressure varied between 140/80 and 180/110, but no systematic relationship to salt administration could be detected. The patient was ambulatory throughout, except for the first 2 days of Period 1 and for several days in Periods 9 and 10, when weakness, dizziness and mental depression led to inactivity. On both occasions symptomatic improvement followed the administration of sodium chloride.

In this patient restriction of sodium chloride produced some of the effects stated to be characteristic of Addison's disease (Harrop et al. (1933)). Blood pressure was, however, never below normal and, during the period shown in Figure 1, was uniformly conspicuously above normal. There was no distinctive pigmentation of the skin or mucous membranes. Retrograde pyelography revealed normal, sharply defined pelves and calices. Conspicuous renal insufficiency, organic in type, was the outstanding feature and persisted even when large doses of sodium chloride were given. If Addison's disease was present in addition it was not yet recognizable clinically.

Table IV presents a detailed comparison of 12 hour creatinine and urea clearances during $\mathrm{Pe}$ riods 9,10 and 11 . During the fourth day of salt restriction both urea and creatinine clearances reached their lowest levels. Creatinine clearances averaged $8.3 \mathrm{cc}$. per minute during the 4 days of salt restriction, and $10.1 \mathrm{cc}$. per minute when salt was administered. Creatinine clearance fell more rapidly and recovered more quickly after the restriction, and the administration respectively, of sodium chloride. The effect cannot be ascribed to changes in urine flow which have little or no influence on creatinine clearance (Holten and Rehberg (1931)). With respect to urea also there should be no grave error ascribable to changes in urine flow, since the rate of urine formation was relatively constant and since urea clearances were computed from the Van Slyke equations. Using the equation for "standard" clearance when the rate of urine formation was below $2.0 \mathrm{cc}$. makes the recorded differences in urea clearance less than they would have been if no correction had been made for diuresis. Hence any error in calculated urea clearances is in the direction of minimizing the changes under observation. Moreover, the observation described in Table IV agrees with that in Table III, though the rate of urine formation differed considerably in the two series. In this patient at two levels of diuresis, therefore, sodium chloride administration appeared to modify the facility with which urea and creatinine were excreted by markedly insufficient kidneys.

On discharge, the patient had no symptoms referable to azotemia ; the plasma urea nitrogen was $34.6 \mathrm{mgm}$. per $100 \mathrm{cc}$., creatinine $4.7 \mathrm{mgm}$. per 100 cc., plasma chloride 100 m.eq. per liter, serum phosphates $5.9 \mathrm{mgm}$. per $100 \mathrm{cc}$. One month later, with 15 grams of sodium chloride per day, low protein diet and $3000 \mathrm{cc}$. of fluid per day, the plasma chlorides were 100 m.eq. per liter, the plasma urea nitrogen $27.8 \mathrm{mgm}$. per $100 \mathrm{cc}$., and the plasma creatinine $4.9 \mathrm{mgm}$. per $100 \mathrm{cc}$.

Case 2, F. M., white male, aged 46, was first admitted to the Medical Ward May 12, 1934. He presented gross 
hematuria, edema, hypertension and azotemia. Phenolsulphonphthalein elimination was reduced at first to a trace in 2 hours. Diuresis set in and renal function improved steadily except for a brief period after tonsillectomy; on discharge a 2-hour urea clearance indicated 30 per cent of average normal function and phenolsulphonphthalein elimination was 25 per cent in 2 hours. He was discharged on July 26,1934 , with a diagnosis of subsiding acute glomerulonephritis. was readmitted for further study. In the course of this second admission the relation between sodium chloride intake and urea clearance was studied.

The patient was ambulatory. A rigid salt-poor diet containing 2700 calories and 1.0 gram of protein per kilo daily was used. Fluid intake was kept at $3000 \mathrm{cc}$. per day throughout. Figure 2

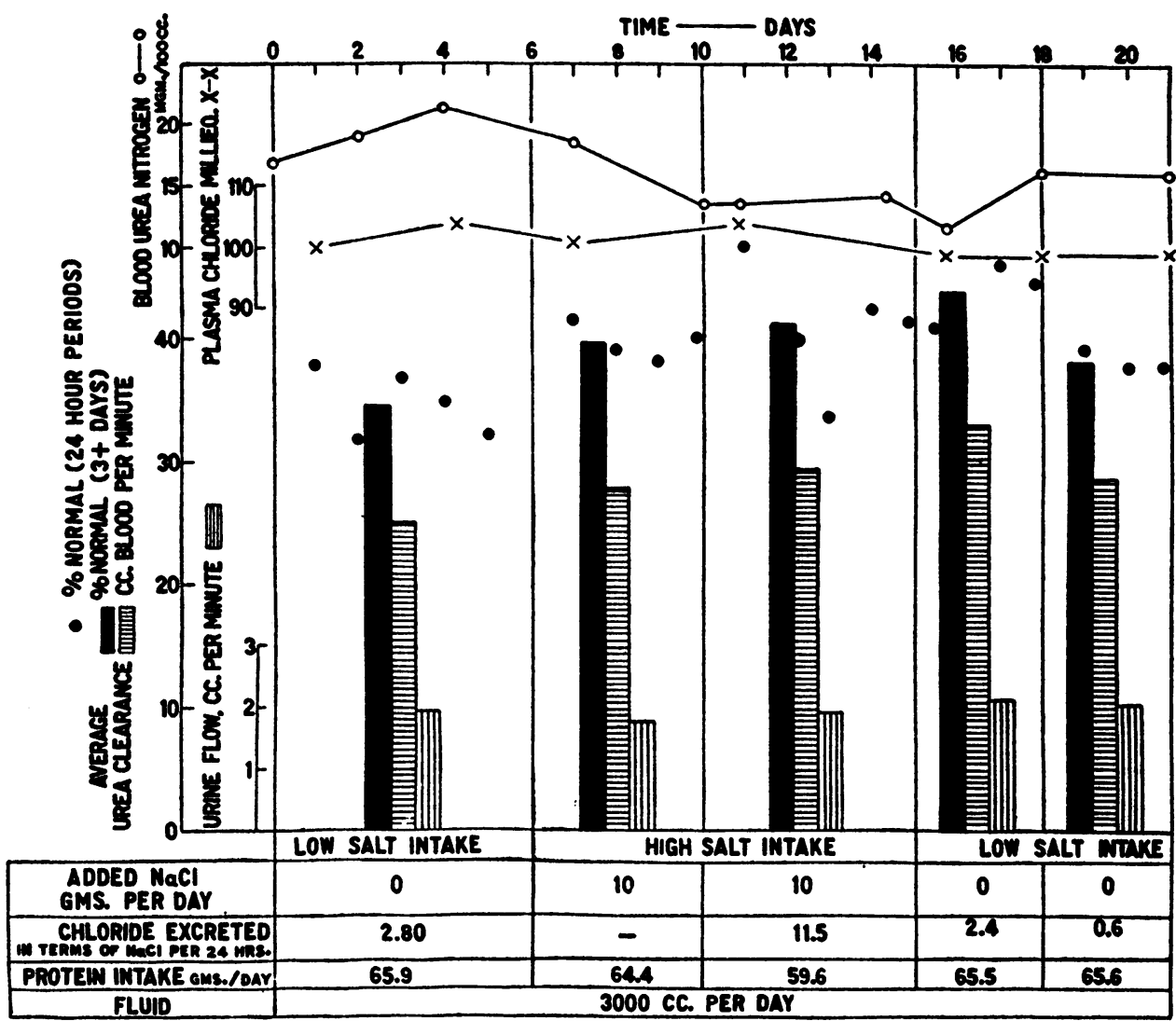

Fig. 2. Case 2. Showing Effects of Administering and Restricting Sodium Chloride in a Patient with Slight Renal Insufficiency.

In October, 1934, a concentration test and cast count yielded the following results: Restriction of fluids for 24 hours (Addis) elevated the specific gravity of the urine to 1.018. The 12-hour volume was $720 \mathrm{cc}$., the reaction acid. Cast excretion totalled 79,000 per 12 hours with 45 per cent hyaline, 12 per cent granular, 10 per cent blood and 33 per cent epithelial casts. Erythrocyte excretion was 450 million per 12 hours, the urinary sediment being definitely red. Epithelial cells and leukocytes numbered 0.7 million in 12 hours. The plasma urea nitrogen was $16.6 \mathrm{mgm}$. per $100 \mathrm{cc}$. A 2-hour urea clearance showed 62 per cent of normal function, the plasma proteins were normal and the 12 -hour specimen of urine contained $0.42 \mathrm{gram}$ of protein. In view of persisting (active) subacute glomerulonephritis the patient shows plasma urea nitrogen (circles), plasma chloride (crosses) and 24-hour urea clearances (dots) over 14 days. The shaded areas represent average urea clearance in terms of per cent normal function (solid), urea clearance in terms of cc. plasma cleared per minute (horizontal lines) and the average rate of urine formation (vertical lines).

For the first 6 days no salt was given except for that in the diet (less than 1.0 gram per day). Plasma chloride did not change, body weight diminished by 0.5 pound, and the average chloride 
elimination was reduced to 2.80 grams per day. Average urea clearance was 34.7 per cent of normal and blood urea nitrogen rose from 16.9 to a maximum of $21.7 \mathrm{mgm}$. per $100 \mathrm{cc}$.

The administration of 10 grams of salt per day in the form of half-strength physiological salt solution was accompanied by a gain of 3.7 pounds in weight and by a fall of plasma urea nitrogen to $11.8 \mathrm{mgm}$. per $100 \mathrm{cc}$., with a definite increase of average urea clearance whether considered in terms of per cent normal, or simply in terms of cc. plasma cleared per minute. Protein intake was constant except for a period of slight anorexia during the last few days of high salt intake.

Reducing the sodium chloride intake, other things being constant, again diminished body weight by 3 pounds, the change being complete by the end of the third day of chloride restriction. The rate of urine formation increased during this time and the higher urea clearance observed may be due in part to the diuresis accompanying loss of body chloride and water. During chloride restriction the urine contained at first 2.4 grams of chloride (as $\mathrm{NaCl}$ ) per day, and later 0.6 gram. In the latter part of the second period of chloride restriction the average urea clearance approached the level observed during the initial period of low salt intake. Plasma chlorides remained constant but the plasma urea nitrogen rose from 11.6 to $16.2 \mathrm{mgm}$. per $100 \mathrm{cc}$.

Case 3, L. F., white male, aged 61 , had been admitted to the hospital on several occasions since 1928 on account of marked hypertension $(230 \mathrm{~mm}$. $\mathrm{Hg}$ systolic and 140 $\mathrm{mm}$. $\mathrm{Hg}$ diastolic), generalized arteriosclerosis, moderate obstructive symptoms from prostatic median bar (relieved in 1932 by cystoscopic resection) and chronic cystitis. A moderate grade of renal insufficiency was present. Phenolsulphonphthalein elimination amounted to 30 per cent in 2 hours.

Restriction of fluids for 24 hours elevated the specific gravity of the urine to 1.017 , the 12 -hour volume being $855 \mathrm{cc}$. The blood urea nitrogen varied between 20 and $30 \mathrm{mgm}$. per $100 \mathrm{cc}$; a 2-hour urea clearance revealed 35 per cent normal function. Creatinine clearance amounted to $44 \mathrm{cc}$. per minute. Plasma proteins were 8.07 per cent, and the urinary excretion of protein amounted to $0.13 \mathrm{gram}$ per 12 hours. The excretion of many leukocytes, owing to cystitis, prevented computing erythrocyte and cast excretion.

This patient was studied for 14 days with the results shown in Figure 3, by symbols similar to

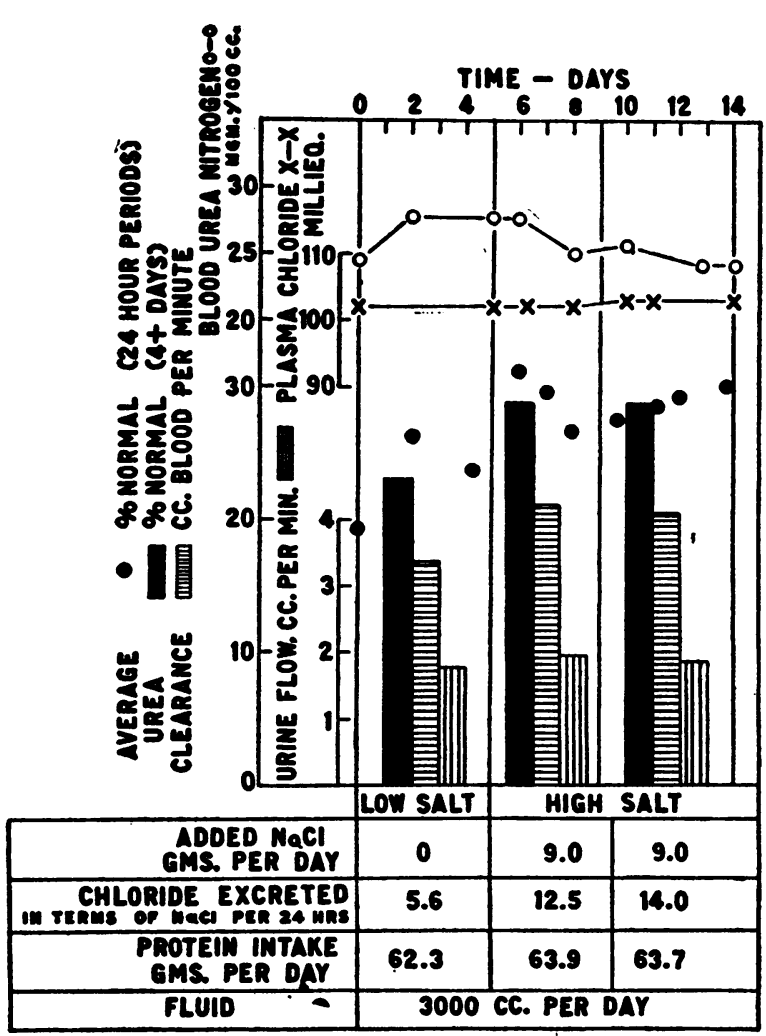

Fig. 3. Case 3. Showing Effects of Administering and Restricting Sodium Chloride in a Patient with Moderate Renal Insufficiency.

those in Figures 1 and 2. The patient was placed on a diet containing 2500 calories and 1.0 gram of protein per kilo. Protein intake was practically constant, and fluid intake was kept to 3000 cc. per day. The diet was not so rigidly salt-poor, milk and salt-containing bread being allowed. The patient was ambulatory throughout.

During the first 5 days no salt was added to the diet, the output in the urine being 5.6 grams per day. Body weight was reduced by 1 pound. Blood urea nitrogen rose from 21.7 to $27.7 \mathrm{mgm}$. per 100 cc., remaining constant at the latter level. Plasma chloride was not altered. The 24-hour urea clearances averaged 23.5 per cent of normal.

During the succeeding 9 days, 9.0 grams of salt were added to the diet by substituting $2000 \mathrm{cc}$. of half-strength physiological salt solution for an equal amount of water in the fluid intake. Body weight increased by 2 pounds. The plasma urea nitrogen fell from 27.7 to $24.3 \mathrm{mgm}$. per $100 \mathrm{cc}$., the average urea clearance rising from 23.5 to between 29.2 and 28.9 per cent of normal during 
TABLE $\mathbf{V}$

Summary of observations during $\mathrm{NaCl}$ administration and restriction

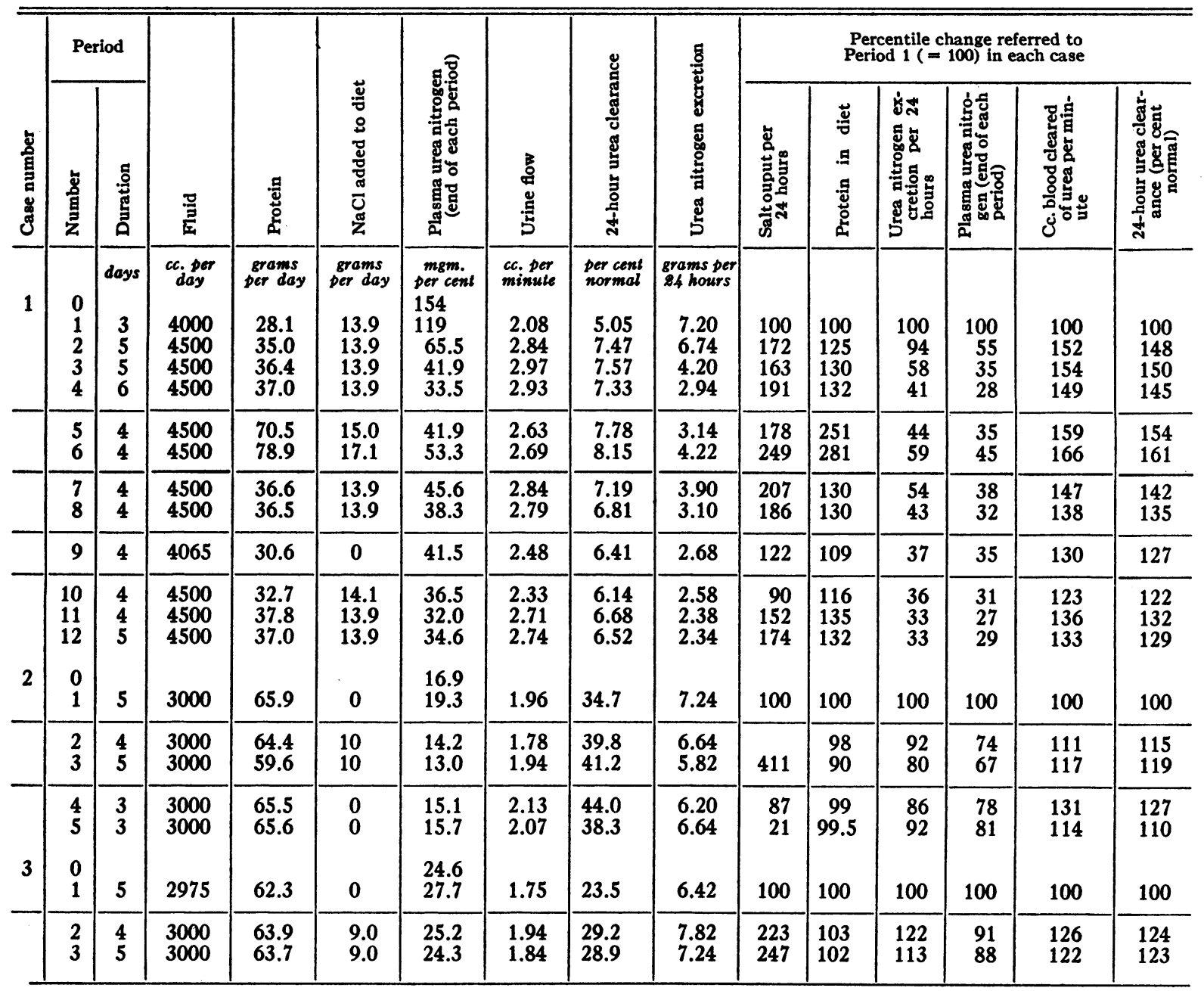

salt administration. Mild grades of salt restriction and administration were used since the marked hypertension made it inadvisable to test extreme conditions. Severe headache complained of before admission disappeared during salt restriction, but returned in mild grade during the last few days of salt administration.

The important average figures for each of the 3 cases are summarized in Table V. Absolute values are given in the left hand portion of the table. Percentile changes during the period of study are shown at the right; for quantitative comparison the various values applying to the first period for each case have been taken as 100 per cent, each subsequent period being compared to Period 1.
In Case 1 salt excretion was doubled at the time urea clearance was highest ( 66 per cent above the urea clearance for Period 1). The times in which urea clearance was lowest (Periods 1,9 and 10) were those in which salt excretion was least. Urea nitrogen excretion was greatest shortly after admission ( 7.20 grams per 24 hours) falling to a minimum of 2.34 grams per 24 hours in Period 12 , showing no definite relation to urea clearance. It would seem that the excessive excretion of urea nitrogen during the early periods resulted simply from the elimination of retained urea. The elimination of urea nitrogen was finally reduced to 33 per cent of the initial value, and the blood urea nitrogen was reduced to 29 per cent of the initial value. 
Protein intake was approximately constant in Case 1, except for Periods 1 and 9, owing to anorexia, and Periods 5 and 6 when protein intake was purposely increased. The observed reduction in urea clearance and elevation of blood urea nitrogen cannot be explained by the slight change in protein intake during the low salt period. The similarity in the percentile changes in urea clearance (per cent of normal) and cc. of plasma cleared of urea per minute indicates that changes in the rate of urea excretion are demonstrable by either method of calculation and do not depend upon the more or less arbitrary use of the square root of the rate of urine formation contained in Van Slyke's equation for calculating standard clearances. This equation was used in isolated instances in Periods 1, 2, 5, 9 and 10. In other periods the clearances were maximal since the average rate of urine formation was usually above $2.0 \mathrm{cc}$. per minute.

In Case 2 chloride excretion was increased fourfold in Period 3 and urea clearance was 17 per cent higher than in Period 1 when salt intake was low. The total urea excretion was lower, however, partly by reason of voluntarily reduced protein intake. As in Case 1, moreover, the effects of salt restriction were not evident immediately. Loss of weight showed that body fluid was being diminished. The sodium chloride thus made available might delay for some days the effects of chloride restriction. Similar lag in the excretory response to the administration and restriction of chloride is described by Rowntree and Fitz (1913), Vallery-Radot (1918) and by Leiter (1926) who emphasize the importance of body fluids and tissue in connection with salt balances. Our own observations with chloride-poor diets in patients with edema indicate that the urinary excretion of chloride remains high until the edema fluid has been excreted. Only after weeks will reduction in chloride intake produce in edematous patients the reduction of urea clearance that is observed in non-edematous individuals after 4 to 5 days.

In Case 3 protein intake was more constant and the increased urea clearance was associated also with increased total excretion of urea nitrogen, while salt output was doubled.

The studies of 3 patients with different grades of renal insufficiency agree in showing during salt administration (1) a tendency toward lower plasma urea nitrogen, (2) a slight increase in the volume of plasma cleared of urea per minute and (3) slightly increased urea clearance over 12- and 24-hour periods when calculated by the Van Slyke equation in terms of per cent of normal.

\section{Urea clearances and diuresis during day and night}

In the 3 patients with renal insufficiency urine was collected in two 12-hour periods extending from 8 p.m. to 8 a.m., and from 8 a.m. to 8 p.m., in order to detect any large differences in urea clearance that might be related to diurnal change in the rate of urine formation, or to diurnal changes in excretory activity. The 12 -hour urea and creatinine clearances shown in Table IV do not show any striking or uniform relation to the period of urine collection. It should be mentioned, however, that while urea clearances varied irregularly, creatinine clearances were lower by night in 11 of 15 periods, and higher by night in the remainder, though the differences were extremely slight.

The data on Cases 1 and 2 are charted in Figure 4 , to compare the rate of urine formation and urea clearance in night and day periods. Solid dots refer to the night period from $8 \mathrm{p} . \mathrm{m}$. to 8 a.m., circles to the day period from 8 a.m. to 8 p.m. The charts show no systematic relation between day and night urea clearances, the distribution of points being in general haphazard.

The rate of urine formation in Case 1 tended to be very slightly higher during the night, but the variation was slight as is usually the case in renal insufficiency. There was no uniform relation between urea clearance and the diuresis. This is to be expected since clearances were, with two exceptions, maximal (i. e., associated with urine formation at rates exceeding $2.0 \mathrm{cc}$. per minute). While salt was being given, the rate of urine formation was occasionally less than $2.0 \mathrm{cc}$. per minute (Figure 4, Periods 2 and 5) but the urea clearance in terms of per cent of normal remained at the usual level. In Case 1 the low clearances associated with salt restriction were accompanied by slightly lower rates of urine formation, the lowest corresponding to over $2300 \mathrm{cc}$. per 24 hours. Since occasional relative oliguria in 

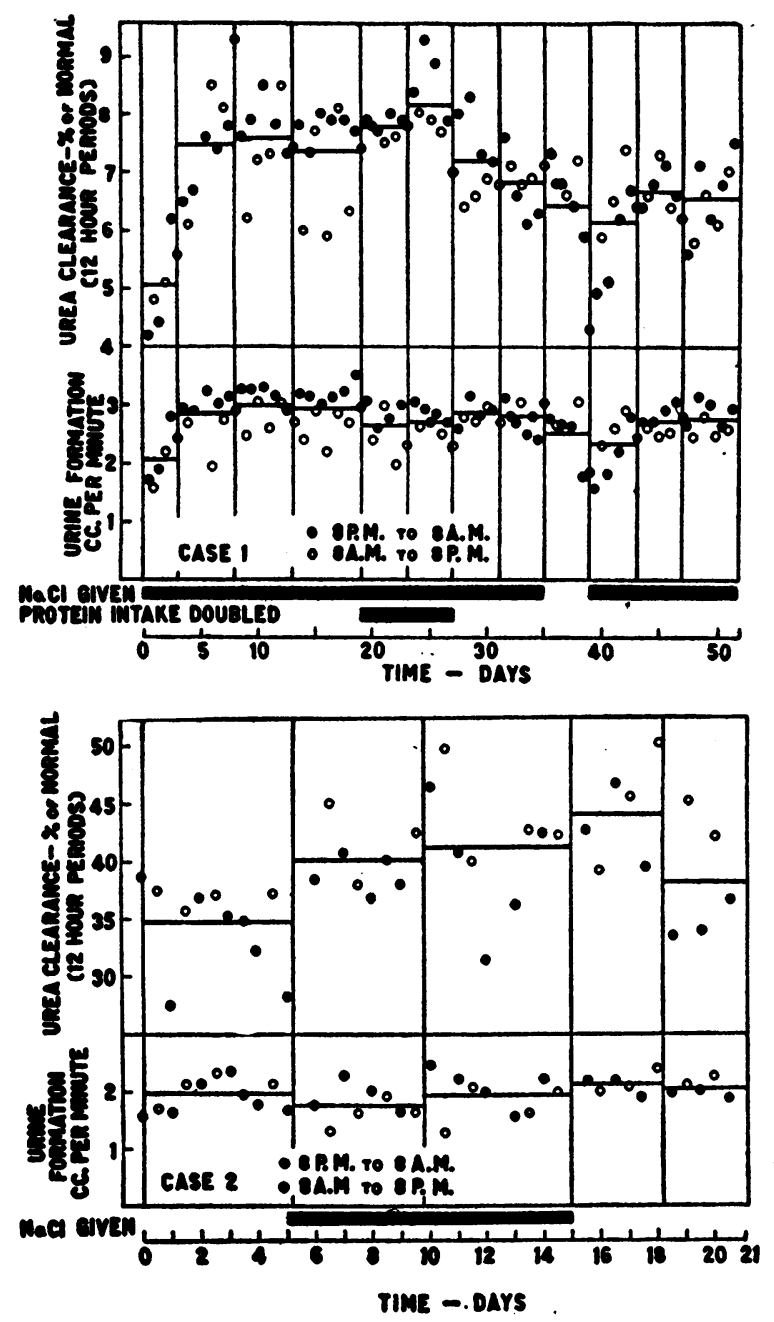

Fig. 4. Cases 1 and 2. Showing Urea Clearance (Per Cent Normal) and Diuresis During Day ( 8 A.M. to 8 P.M., Circles) aNd Night (8 P.M. to 8 A.M., Dots) Periods.

the periods of salt administration did not affect urea clearance measurably, it seems most unlikely that the low urea clearances observed during hypochloremia were secondary to relative oliguria alone.

In Case 2 (Figure 4) diuresis was relatively constant, while 12-hour clearances varied more widely. There were no definite diurnal variations. The diurnal fluctuations in renal excretion described by Simpson (1926), Norn (1929) and Manchester (1932) while conspicuous, were of short duration and would in large measure be neutralized by 12 -hour periods of collection, particularly since the night specimens included the urine formed immediately before and after sleep. Manchester (1932) found nitrogen excretion very slightly greater in the daytime, but stated that the increase in specific gravity of the night urine was due largely to nitrogenous substances in spite of the fact that the total amount of urinary nitrogen excreted was slightly smaller during the night. Moreover, it is to be expected that patients with renal insufficiency would not show significant diurnal variations in excretion since the disappearance of nocturnal relative oliguria is one of the first indications of renal insufficiency.

\section{DISCUSSION}

A number of clinical reports indicate that chloride administration may be helpful in reducing azotemia in selected cases (Vallery-Radot (1914), Romalo and Dumitresco (1914), Blum et al. (1929), Borst (1931)), though adverse effects from the administration of large doses of sodium chloride have also been observed (Veil (1918), Lemierre et al. (1929)). The findings in Case 1 resemble those of a case described by Chabanier et al. (1934). A patient with chronic glomerulonephritis showed vomiting, convulsions and oliguria, associated with a blood urea of $542 \mathrm{mgm}$. per $100 \mathrm{cc}$. and a blood chloride of $250 \mathrm{mgm}$. per $100 \mathrm{cc}$. The administration of sodium chloride diminished the oliguria and eventually lowered the blood urea to $25 \mathrm{mgm}$. per $100 \mathrm{cc}$. Renal function in Chabanier's patient was 10 per cent of normal, according to the Ambard coefficient.

In agreement with the data of McLester (1922) and of Allen and Sherrill (1922) it appears that restriction of sodium chloride may be associated with elevation of plasma urea nitrogen with or without lowering of plasma chlorides. The observations made during the administration of salt agree in general with those of Hatcher and Sollmann (1902) and Schoenthal (1929). If the changes in 24-hour urea clearances described for the three patients studied prove to be significant, it would seem that the greater variability of 2-hour urea clearances will explain the negative results of Leiter (1926) and Cope (1933). The wide range of normal variation often observed in short period studies of renal function may have concealed the relatively slight changes in urea clearance required to produce the cumulative 
effects that are represented by a slight elevation of the concentration of blood urea nitrogen. It may be added that 2 -hour urea clearances, determined in the course of our studies of 3 patients, did not show changes which could be ascribed to differences in salt intake; during the same period the 24-hour urea clearance indicated the small, but apparently consistent, changes recorded.

Chaussin (1920) found that when fluid is restricted the administration of chlorides in large doses diminishes the excretion of urea. Davies, Haldane and Peskett (1922) observed that the maximal possible molecular concentration of chloride in the urine is 0.33 normal, and that the total molecular concentration of chlorides plus bicarbonate cannot exceed this figure. They believed, however, that the excretion of urea and chlorides were not interdependent. According to Adolph (1923) the total molecular concentration of the urine does not ordinarily exceed a fixed value, and if the concentration of one substance approaches this value in the urine the excretion of other substances will be depressed. These findings are not opposed to our own, since fluid intake was liberal enough to avoid the excretion of highly concentrated urine. The amount of fluid was graded so that the specific gravity of the urine was below the maximum characteristic for each patient. Under these conditions the antagonism described above could not be an important limiting factor.

Our observations yield no specific information concerning the importance of the total osmotic concentration of the blood in determining nitrogen retention. The finding of a measurable, though small, change in urea clearance suggests, however, that depressed renal function per se may play a part in the development of azotemia in those conditions which are characterized by the loss of large amounts of chloride.

The identification of the exact mechanism by which renal function can be reduced during chloride restriction must await further opportunity to study other patients with hypochloremia and conspicuous azotemia. In Case 1 the reduced intake of sodium chloride apparently tended to diminish both the urea and creatinine clearances. It is known that loss of chloride produces dehydration and anhydremia; plasma volume is reduced and the concentration of plasma protein is increased (Veil (1918)). It is conceivable that the anhydremia of salt restriction may affect creatinine clearance in the same way that the anhydremia of standing does. According to $\mathrm{Ni}$ and Rehberg (1931) creatinine clearance and glomerular filtration are less in the standing position because blood volume is reduced and plasma protein concentration increased, by filtration of relatively proteinfree filtrate from the blood stream into the dependent parts of the body. The coincident depression of urea and creatinine clearances suggests that reduced glomerular filtration may be in part responsible. A definite decision on this point cannot be made with the limited data now available. The results thus far obtained are described since this method of study may help in determining the mechanism through which depletion of sodium chloride favors the development of azotemia in certain patients.

\section{SUM MARY}

In 2 normal subjects urea clearances determined over 24-hour periods varied less widely than did the conventional urea clearances determined over 1-hour periods. Average urea clearances over 12- and 24-hour periods were therefore used to study possible effects of sodium chloride restriction and administration on renal function in 3 patients with different grades of renal insufficiency.

When diet and fluid intake were kept constant, a restricted intake of sodium chloride was accompanied by a slight elevation of plasma urea nitrogen concentration and by a slightly diminished average 24-hour urea clearance. Administration of sodium chloride was accompanied by a lowering of plasma urea nitrogen concentration and by a higher average 24-hour urea clearance.

In one patient with advanced renal insufficiency the plasma urea nitrogen decreased from 154 to $26 \mathrm{mgm}$. per $100 \mathrm{cc}$. during sodium chloride administration. Acute restriction of sodium chloride intake produced hypochloremia with characteristic symptoms. In addition, there was temporary retention of urea, creatinine and phosphates. Renewed sodium chloride administration relieved the symptoms and diminished the concentrations of urea, creatinine and phosphate in the plasma. 
In this same patient both the urea and the creatinine clearances over 24-hour periods were slightly lower during and shortly after sodium chloride restriction, becoming somewhat higher during sodium chloride administration.

It is suggested that this method of study applied to suitable cases may aid in determining the factors responsible for the association, in certain patients, of hypochloremia and azotemia.

\section{BIBLIOGRAPHY}

1. Adolph, E. F., The excretion of water by the kidneys. Am. J. Physiol., 1923, 65, 419.

2. Allen, F. M., and Sherrill, J. W., The treatment of arterial hypertension. J. Metabolic Research, 1922, 2, 429.

3. Blum, L., Van Caulaert, C., and Grabar, P., Phénomènes d'hypochloruration apparaissant chez un urémique traité par le régime sans sel. Bull. et mém. Soc. méd. d. hôp. de Paris, 1929, 53, 251.

4. Blum, L., Grabar, P., and Van Caulaert, C., L'Azotémie par manque de sel, dans le diabéte grave. Ann. de méd., 1929a, 25, 23.

5. Blum, L., Grabar, P., and Van Caulaert, C., L'Azotémie par manque de sel, son mécanisme. Ann. de méd., 1929b, 25, 34.

6. Borst, J. G. G., Urämie durch Kochsalzmangel. Ztschr. f. klin. Med., 1931, 117, 55.

7. Brown, G. E., Eusterman, G. B., Hartman, H. R., and Rowntree, L. G., Toxic nephritis in pyloric and duodenal obstruction. Renal insufficiency complicating gastric tetany. Arch. Int. Med., 1923, 32, 425.

8. Bruger, M., and Mosenthal, H. O., Urea clearance test as an index of renal function. I. Studies of normal subjects. Arch. Int. Med., 1932, 50, 351.

9. Chabanier, H., Lobo-Onell, C., Lieutaud, P., and Lelu, E., Poussée aiguë d'hyperazotémie avec phénomènes urémiques graves liée à une hypochlorémie chez un néphritique chronique. Presse méd., 1934, 42, 844.

10. Chaussin, J., Antagonisme de concentrations entre les principales substances dissoutes dans l'urine de l'homme et des herbivores. J. de Physiol. et path. gén., 1920, 18, 895.

11. Cope, C. L., Studies of urea excretion. VIII. The effects on the urea clearance of changes in protein and salt contents of the diet. J. Clin. Invest., 1933, $12,567$.

12. Davies, H. W., Haldane, J. B. S., and Peskett, G. L., The excretion of chlorides and bicarbonates by the human kidney. J. Physiol., 1922, 56, 269.

13. Derrick, E. H., Heat cramps and uraemic cramps, with special reference to their treatment with sodium chloride. M. J. Australia, 1934, 2, 612.

14. de Wesselow, O. L. V., The excretion of chlorides by the healthy and diseased kidney. Quart. J. Med., $1925-6,19,53$.

15. Eisenman, A. J., Note on the Van Slyke method for the determination of chlorides in blood and tissue. J. Biol. Chem., 1929, 82, 411.

16. Folin, O., and Denis, W., The quantitative determination of albumin in urine. J. Biol. Chem., 1914, 18, 273.

17. Gram, H. C., Observations on the regulation of osmotic pressure (conductivity, chlorides, freezing point, and proteins of serum). J. Biol. Chem., 1923, 56, 593.

18. Haden, R. L., and Guffey, D. C., A case of pernicious vomiting of pregnancy with low blood chlorides and marked response to sodium chloride therapy. Am. J. Obst. and Gynec., 1924, 8, 486.

19. Harrop, G. A., Weinstein, A., Soffer, L. J., and Trescher, J. H., The diagnosis and treatment of Addison's disease. J. A. M. A., 1933, 100, 1850.

20. Hartmann, A. F., and Darrow, D. C., Chemical changes occurring in the body as a result of certain diseases in infants and children. II. Acute hemorrhagic nephritis. Sub-acute nephritis; severe chronic nephritis. J. Clin. Invest., 1928, 6, 127.

21. Hatcher, R. A., and Sollmann, T., The effect of diminished excretion of sodium chloride on the constituents of the urine. Am. J. Physiol., 1902, 8, 139.

22. Holten, C., and Rehberg, P. B., Studies on the pathological function of the kidneys in renal disease, especially Bright's disease. Acta med. Scandinav., 1931, 74, 479.

23. Kerpel-Fronius, E., and Butler, A. M., Salt and water losses in diuretin diuresis and their relation to serum nonprotein nitrogen and electrolyte concentrations. J. Exper. Med., 1935, 61, 157.

24. Leiter, L., Influence of previous salt regime on excretions of chlorine, sodium and potassium during the chloride concentration test of de Wesselow. J. Clin. Invest., 1926, 3, 253.

25. Lemierre, A., Thurel, R., and Rudolf, M., Hypochlorémie au cours d'une néphrite chronique avec azotémie. Bull. et mém. Soc. méd. d. hôp. de Paris, 1929, 53, 956.

26. McLean, F. C., The numerical laws governing the rate of excretion of urea and chlorides in man. II. The influence of pathological conditions and of drugs on excretion. J. Exper. Med., 1915, 22, 366.

27. McLean, F. C., The chlorides of the plasma in uremia. Proc. Soc. Exper. Biol. and Med., 1916, 13, 166.

28. McLester, J. S., The influence of rigid salt restriction in the diet of chronic nephritis. Am. J. M. Sc., 1922, 163, 794.

29. Manchester, R. C., The diurnal rhythm in water and mineral exchange. J. Clin. Invest., 1932, 12, 995.

30. Mellinghoff, K., Über Urämie bei Kochsalzmangel. Deutsche med. Wchnschr., 1934, 60, 1127. 
31. Meyer, P., Intoxikation mit Eiweisszerfall (Scheinurämie) infolge Erbrechens. Klin. Wchnschr., 1932, 11, 1383.

32. Möller, E., McIntosh, J. F., and Van Slyke, D. D., Studies of urea excretion. II. Relationship between urine volume and the rate of urea excretion by normal adults. J. Clin. Invest., 1928, 6, 427.

33. Morawitz, P., and Schloss, J., "Extrarenale" albuminurie und urämie. Klin. Wchnschr., 1932, 11, 1628.

34. Moss, K. N., Some effects of high air temperatures and muscular exertion upon colliers. Proc. Roy. Soc. London, s.B, 1923-4, 95, 181.

35. Ni, T. G., and Rehberg, P. B., On the influence of posture on kidney function. J. Physiol., 1931, 71, 331.

36. Norn, M., Untersuchungen über das Verhalten des Kaliums im Organismus. II. Uber schwankungen der Kalium-, Natrium- und Chloridausscheidung durch die Niere im Laufe des Tages. Skandinav. Arch. f. Physiol., 1929, 55, 184.

37. Page, I. H., The effect on renal efficiency of lowering arterial blood pressure in cases of essential hypertension and nephritis. J. Clin. Invest., 1934, 13, 909.

38. Peters, J. P., Salt and water metabolism in nephritis. Medicine, 1932, 11, 435.

39. Romalo, E., and Dumitresco, Administration du chlorure de sodium aux néphrétiques, chlorurémiques et azotémiques. Compt. rend. Soc. de biol., 1914, 76, 676.

40. Rowntree, L. G., and Fitz, R., Studies of renal func- tion in renal, cardiorenal and cardiac diseases. Arch. Int. Med., 1913, 11, 258.

41. Salvesen, H. A., Variations in the serum electrolytes in diseases of renal origin with special reference to the cause of renal acidosis. Acta med. Scandinav., 1928, 69, 126.

42. Schoenthal, L., Acid base metabolism. Effects of administration of salt and of restriction of water. Am. J. Dis. Child., 1929, 37, 244.

43. Simpson, G. E., The effect of sleep on urinary chlorides and pH. J. Biol. Chem., 1926, 67, 505.

44. Talbott, J. H., and Michelsen, J., Heat cramps. A clinical and chemical study. J. Clin. Invest., 1933, 12, 533.

45. Vallery-Radot, P., Variations du taux de l'urée sanguine chez les Brightiques azotémiques sous l'influence de l'ingestion de chlorure de sodium. Compt. rend. Soc. de biol., 1914, 76, 760.

46. Vallery-Radot, P., Rhythme en échelons de la rétention chlorure. Presse méd., 1918, 26, 135.

47. Van Slyke, D. D., Alving A., and Rose, W. C., Studies of urea excretion. VII. The effects of posture and exercise on urea excretion. J. Clin. Invest., 1932, 11, 1053.

48. Van Slyke, D. D., and Cullen, G. E., A permanent preparation of urease, and its use in the determination of urea. J. Biol. Chem., 1914, 19, 211.

49. Veil, W. H., ther die Bedeutung intermediärer Veränderungen im Chlorstoff wechsel beim Normalen und beim Nierenkranken. Biochem. Ztschr., 1918, 91, 267. 